\section{Relationship Between Writing Motivation Levels and Writing Skills Among Secondary School Students}

\author{
Üzeyir Süğümlüa, ${ }^{\star}$, Hasan Hüseyin Mutlu ${ }^{b}$, Enes Çinpolat ${ }^{c}$
}

\author{
Received: 19 March 2019 \\ Revised: 24 May 2019 \\ Accepted: 01 June 2019 \\ ISSN: 1307-9298 \\ Copyright (C) IEJEE \\ www.iejee.com
}

\begin{abstract}
The aim of this study was to determine the relationship between the writing motivation levels and written expression skills among secondary school students. The study was carried out using the correlational research model of the quantitative research methods. The study group for this study consisted of 230 students attending three different secondary schools in the fall semester of the 2018-2019 school year. For the selection of the study group, the convenient sampling method of the non-probabilistic sampling methods was used. The data collection tools for this study were the writing motivation scale, the writing evaluation form and a personal information form. The writing studies were assessed separately by three researchers. Statistical analyses were performed on the data collected from the writing motivation scale, which was applied to determine the writing motivation levels of the students, and the writing evaluation form, which was assessed using the writing studies. Based on the findings of this study students with high writing motivation scores had high writing evaluation scores.
\end{abstract}

Keywords: Writing Skills, Writing Motivation, Writing Study, Secondary School Students

\section{Introduction}

The goals of language learning and teaching should be based on the needs of students and society, in-class applications required to meet these needs, activities and processes and the skills and proficiencies that students are required to improve in order to realize all of these aims (Council of Europe, 2001). Language teaching occurs through two basic comprehension-based skills which are listening and reading and two production based skills which are speaking and writing (Karadağ \& Maden, 2013). Writing is an important skill that constitutes the last stage of effective language learning achieved through education, similar to reading, included in the narration area of language.

In addition to language skills, writing skills also support students in expanding their thoughts, regulating their knowledge, using the language, enriching their intelligence and improving their mental lexicon by being in touch with mental processes (Güneş, 2013). Students transfer knowledge and review and regulate their thoughts more efficiently as their writing skills improve which consequently enables them to write at higher levels (Akyol, 2013). Bağcı Ayrancı (2013) stated that writing is a production skill and, with this skill, people have the opportunity to explain their thoughts and feelings accurately, efficiently and permanently. In brief, it is possible to assess writing as a skill comprising the processes of expressing emotions, thoughts and information through written communication channels (Carter, Bishop \& Kravits, 2002).

Writing is defined as a complicated process involving a range of skills and functions (The Ontario Curriculum Language, 2006) that encompass planning, creating (writing and developing), editing and publishing printed or digital texts (The Australian Curriculum English, 2012). The stages of the process of writing are stated as being planning, creating a draft, reviewing, editing, rereading and publishing (The Ontario Curriculum Language, 2006). According to the Writing and Writing Skills Lesson Curriculum (2018), the writing process was comprised of the preparation, planning, developing, editing and presentation stages. Many researchers have also stated that writing is a skill that consists of certain processes (Akyol, 2013; Arıcı \& Ungan; 2017; Güneş, 2013; Karatay, 2013; Tekșan, 2013; Yıldız, Okur, Arı \& Yılmaz, 2013). Other researchers have reported that the process of writing which is carried out incrementally has an important role in the development of students' written expression skills (Bruning \& Horn, 2000; Graham \& Sandmel, 2011; Karatay, 2013). In the writing skill that requires a process, the motivation of students becomes important in the development of their writing skills.

In the last 30 years, motivation has become an important element in the experimental and conceptual studies conducted on mother tongue and second language learning (Vaezi, 2008). Motivation has been determined as a necessary factor for successful language learning (Dörnyei, 2001) and has been elevated to a key place in successful learning (Wachob, 2006). Kellogg (2008) stated that writing skills begin to develop in childhood and continue to develop over a period of more than 20 years. It is clear that, within this long period, student motivation levels are determinants in writing skills. Student writing motivation involves the whole writing process and appears to be important in terms of transforming a writing action into a product.

Motivation is characterized by both emotional and cognitive movement, and the resulting writing process is also characterized by movement (Nelson, 2007). Harris, Graham and Mason (2006) included motivation in development of writing skills. Akyol and Aktaş (2018) stated that motivation played an important role in the development of students' writing skills. Hidi and Boscolo (2006) listed the elements that affect writing motivation as willingness, possessing sufficient information, an uncomplicated topic, receiving instant feedback and expending continuous effort during writing. Boscolo and Gelati (2007) stated that students' willingness to write generally showed tendency to decrease and disappear, and that most writing studies were seen as boring, monotonous and tiring by students. It appears there is a direct relationship between writing skills and writing motivation. Emphasizing the importance of motivation in writing, Ackerman (2006) stated that if there were no methods used to increase motivation when creating a written product, it would not be possible for the person writing (author) to show notable progress and development. Yıldız (2018) stated that, in creating motiva- 
tion among students for writing studies, teachers' enthusiasm also played a role. A study conducted on the correlation between writing motivation and writing skills by Kurudayıoğlu and Karadağ (2010) revealed that most students got bored of writing, were not willing to write and mentioned the difficulty of writing, which revealed negative approaches to writing among students. They stated that it was necessary to encourage students to make writing an enjoyable pastime and habit. Bruning and Horn (2000) stated that motivation had critical importance for the action of writing, and that it was difficult to create and maintain motivation. These studies showed that writing motivation has an important role in making the action of writing sustainable.

A review of the relevant literature determined various studies conducted on the correlation between student writing motivation and written explanation skills (Akyol \& Aktaş, 2018; Canıtezer, 2014; Takımcıgil Özcan, 2014; Troia, Harbaugh, Shankland, Wolbers \& Lawrence, 2013). It was found that the studies conducted in Turkey focused on the relationship between a single class level and writing motivation. The fact that there is no comprehensive research regarding the relationship between the writing motivations and written expression skills of middle-school students constitutes the basis of this study. The present study was carried out with the aim of determining the correlation between writing motivation levels (dependent variable) and written explanation skills (independent variable) among middle school students. In line with this aim, answers were sought for the following research questions:

- Is there a relationship between students' writing motivation and writing study scores?

- Is there a relationship between student gender with writing motivation and writing study scores?

- Is there a relationship between student grade leve with writing motivation and writing study scores?

- Is there a relationship between student writing frequency with writing motivation and writing scores?

\section{Method}

\section{Research Pattern}

This study was carried out with the correlational research model of the quantitative research methods. Correlational studies are non-experimental research studies that make estimations to explain the relationships between variables (Christensen, Johnson \& Turner, 2015). The present study investigated the writing motivation and writing evaluation scores of secondary school students and revealed the correlation between writing motivation and writing skills.

\section{Study Group}

The study group consisted of 230 students attending three different secondary schools in the fall semester of the 20182019 school year. For the selection of the study group, the convenient sampling method (Creswell, 2013; Cohen, Manion \& Morrison, 2007; Robson; 2017) of the non-probabilistic sampling methods was used. A total of 35 students from the $5^{\text {th }}$ grade $(15.21 \%), 65$ from the $6^{\text {th }}$ grade $(28.26 \%), 65$ from the $7^{\text {th }}$ grade $(28.26 \%)$ and 65 from the $8^{\text {th }}$ grade $(28.26 \%)$ participated in this study. The students included in the study group were comprised of 96 boys (41.73\%) and 134 girls (58.26\%).

\section{Data Collection Tools}

The data collection tools used in this study were the writing motivation scale, writing evaluation form and personal information form.

The writing motivation scale developed by Yaman, Süğümlü and Demirtaş (2016) is composed of 4 sub-scales namely, self-efficacy, affective state, social acceptance, and physical state. The number of items in the writing motivation scale is
28 in total. Therefore, the maximum score receivable from this scale, which has 3-point Likert type, is 84 whereas the minimum score is 28 . Four items with negative meaning were encoded inversely in the scale. The Cronbach Alpha value for the scale was .914 while it was .898 for the whole scale in this study.

The other data collection tool in the research was the Writing Evaluation Form developed by the researchers. To develop the writing evaluation form, firstly the literature was screened and an item pool containing 25 items was created. The scope validity of the writing evaluation form was evaluated by three experts in the field and five Turkish teachers. At the end of the assessment, a 17-item, 3-dimension (form, content and style) form was created. The decision was made to use 3-degree scores on the writing evaluation form for the target audience of secondary school students in the study. The items on the writing evaluation form were assessed as insufficient (1), developing (2) and sufficient (3). The reliability coefficient (Cronbach's alpha) for the writing evaluation form was determined as .89.

The personal information form which was also used in this study to collect data was prepared by the researchers to determine the gender, grade level, writing frequency variables of the study group.

\section{Data Collection}

Three secondary schools of middle socio-economic level from Altınordu district of the province of Ordu were selected for the data collection in this study. The necessary permission to collect data was obtained from the Ordu Provincial Directorate of National Education. The teachers were interviewed and were informed about the aim, content and process of the study. The data were collected within two weeks via the teachers. Before collecting the data, the students in the study group were informed about the research process and how the scale items would be read and answered. Firstly, the personal information forms were handed out to students who were gave 15 minutes to complete the forms for each class. Then the Writing Motivation Scale was completed in 40 minutes (one class hour) for every class and then writing studies were performed for 40 minutes in every class. Research data were collected from 254 students. However, 24 students did not participate in the writing study and therefore their scale data were excluded from the scope of this study. An intra-class correlation coefficient was made in order to determine the scoring reliability in the scoring of the writing studies (Landers, 2015; Shrout \& Fleiss, 1979) and a high degree of reliability was found between 3 measurements. The average measure ICC was .924 with a $95 \%$ confidence interval from .905 to $.940\left(F_{(229.458)}=13.156, p<.001\right)$. Data Analysis

The data obtained from the writing motivation scale which was applied to determine the writing motivation levels of students and the writing evaluation form used to assess the writing tasks were statistically analyzed. The IBM SPSS 24.0 statistical program was used for data analysis. The Kolmogorov-Smirnov test was used to test whether data showed normal distribution or not, and as data were not normally distributed, nonparametric tests were used. In terms of the analysis of the data linked to subproblems, the Mann Whitney $U$ test was used for gender and two-way comparisons, the Kruskal Wallis $\mathrm{H}$ test was used for grade level, writing frequency variables, the Pearson product moment correlation coefficient technique was used for correlations between writing motivation and writing scores and simple linear regression was used with the aim of determining how much writing motivation predicted writing success. To test the significance of differences, the significance level was accepted as .05.

\section{Results}

In this section, findings related to gender, grade level, writing frequency of students in the study group and correlations with writing motivation and writing evaluation scores are given. 


\section{Findings Related to Gender}

The correlation of scores received for the writing motivation scale and writing evaluation form in terms of the gender of students is shown in Table 1.

Table 1. Findings Related to Gender

\begin{tabular}{|c|c|c|c|c|c|c|}
\hline & Gender & $N$ & $\begin{array}{r}\text { Mean } \\
\text { Rank }\end{array}$ & $\begin{array}{r}\text { Sum of } \\
\text { Rank }\end{array}$ & $U$ & $p$ \\
\hline \multirow{3}{*}{$\begin{array}{l}\text { WMS } \\
\text { (Writing } \\
\text { Motivation } \\
\text { Scale) }\end{array}$} & Male & 96 & 85.73 & 8230.00 & \multirow[t]{3}{*}{3574.000} & \multirow[t]{3}{*}{$.000^{*}$} \\
\hline & Female & 134 & 136.83 & 18335.00 & & \\
\hline & Total & 230 & & & & \\
\hline \multirow{3}{*}{$\begin{array}{l}\text { WEF } \\
\text { (Writing } \\
\text { Evaluation } \\
\text { Form) }\end{array}$} & Male & 96 & 86.56 & 8309.50 & \multirow[t]{3}{*}{3653.500} & \multirow[t]{3}{*}{$.000^{*}$} \\
\hline & Female & 134 & 136.24 & 18255.50 & & \\
\hline & Total & 230 & & & & \\
\hline
\end{tabular}

It can be seen from Table 1 that there is a significant difference $(U=3574.000, p=.000)$ in favor of the female students regarding motivation. Therefore, it can be said that motivation to write is higher among female students (Mean Rank= 136.83) than male students (Mean Rank= 85.73). Furthermore, when Table 1 is investigated, it can be seen that the students writing evaluation scores differed in favor of female students $(U=3653.500, p=.000)$. Accordingly, the writing evaluation scores of female students (Mean Rank= 136.24) are higher compared to male students (Mean Rank= 86.56).

\section{Findings Related to Grade Level}

The relationship between the writing motivation scores and writing evaluation form scores of the students in terms of grade level is shown in Table 2 .

It can be seen form Table 2 that there is a significant difference in the writing motivation levels of students in terms of grade level $\left(X^{2}=19.692, d f=3, p<.01\right)$. However, the writing evaluation scores did not differ significantly according to grade level. With the aim of determining which groups caused the significant differences, the Kruskall Wallis $\mathrm{H}$ test and the two-way comparison Mann Whitney $U$ test were performed. According to the Mann Whitney $U$ test, there were significant differences between the $5^{\text {th }}$ and $7^{\text {th }}$ grade in favor of the $5^{\text {th }}$ grade $(U=$ $781.000, p=.010)$; between the $5^{\text {th }}$ and $8^{\text {th }}$ grade in favor of the $5^{\text {th }}$ grade $(U=540.500, p=.000)$; and between the $6^{\text {th }}$ and $8^{\text {th }}$ grade in favor of the $6^{\text {th }}$ grade $(U=1444.000, p=.002)$.

Table 2. Findings Related to Grade Level

\begin{tabular}{|c|c|c|c|c|c|c|}
\hline & $\begin{array}{c}\text { Grade } \\
\text { Level }\end{array}$ & $N$ & $\begin{array}{l}\text { Mean } \\
\text { Rank }\end{array}$ & $d f$ & $X^{2}$ & $p$ \\
\hline \multirow{5}{*}{$\begin{array}{l}\text { WMS } \\
\text { (Writing } \\
\text { Motivation } \\
\text { Scale) }\end{array}$} & 5 & 35 & 147.74 & \multirow[t]{5}{*}{3} & \multirow[t]{5}{*}{19.692} & \multirow[t]{5}{*}{$.000 *$} \\
\hline & 6 & 65 & 127.45 & & & \\
\hline & 7 & 65 & 111.02 & & & \\
\hline & 8 & 65 & 90.67 & & & \\
\hline & Total & 230 & & & & \\
\hline \multirow{5}{*}{$\begin{array}{l}\text { WEF } \\
\text { (Writing } \\
\text { Evaluation } \\
\text { Form) }\end{array}$} & 5 & 35 & 122.50 & \multirow[t]{5}{*}{3} & \multirow[t]{5}{*}{3.094} & \multirow[t]{5}{*}{.377} \\
\hline & 6 & 65 & 123.01 & & & \\
\hline & 7 & 65 & 115.51 & & & \\
\hline & 8 & 65 & 104.22 & & & \\
\hline & Total & 230 & & & & \\
\hline
\end{tabular}

\section{Findings Related to The Frequency of Writing}

The correlation of scores received for the writing motivation scale and writing evaluation form in terms of the writing frequency of students is shown in Table 3.

From Table 3, it can be seen that the writing motivation of students differed significantly according to the frequency of writing outside of school $\left(X^{2}=59.193, d f=3, p<.01\right)$. Addition- ally, there was a significant difference in the writing evaluation scores according to non-school writing frequency $\left(X^{2}=\right.$ $51.874, d f=3, p<.01)$. With the aim of determining which groups caused significant differences, the Kruskal Wallis $\mathrm{H}$ test and the two-way comparison Mann Whitney $U$ test were performed. According to the Mann Whitney $U$ test used to determine which groups caused the significant differences in writing motivation in terms of non-school writing frequency, there were significant differences between those who wrote every day and those who wrote once a week in favor of those who wrote every day $(U=2485.000, p=.043)$; between those who wrote every day and those who wrote once a month in favor of those who wrote every day $(U=609.000, p=.000)$; between those who wrote every day and those who wrote less often in favor of those who wrote every day $(U=342.500, p=$ .000); between those who wrote once a week and those who wrote once a month in favor of those who wrote once a week $(U=301.500, p=.000)$; and between those who wrote once a week and those who wrote less often in favor of those who wrote once a week $(U=188.000, p=.000)$.

Table 3. Findings Related to the Frequency of Writing

\begin{tabular}{|c|c|c|c|c|c|c|}
\hline & $\begin{array}{l}\text { Writing } \\
\text { frequency }\end{array}$ & $N$ & $\begin{array}{l}\text { Mean } \\
\text { Rank }\end{array}$ & $d f$ & $x^{2}$ & $p$ \\
\hline \multirow{5}{*}{$\begin{array}{l}\text { WMS } \\
\text { (Writing } \\
\text { Motivation } \\
\text { Scale) }\end{array}$} & Every day & 132 & 138.47 & \multirow[t]{5}{*}{3} & \multirow[t]{5}{*}{59.193} & \multirow[t]{5}{*}{$.000^{*}$} \\
\hline & Once per week & 47 & 117.46 & & & \\
\hline & Once per month & 29 & 57.22 & & & \\
\hline & Less often & 22 & 50.34 & & & \\
\hline & Total & 230 & & & & \\
\hline \multirow{5}{*}{$\begin{array}{l}\text { WEF } \\
\text { (Writing } \\
\text { Evaluation } \\
\text { Form) }\end{array}$} & Every day & 132 & 137.89 & \multirow[t]{5}{*}{3} & \multirow[t]{5}{*}{51.874} & \multirow[t]{5}{*}{$.000^{*}$} \\
\hline & Once per week & 47 & 113.79 & & & \\
\hline & Once per month & 29 & 61.84 & & & \\
\hline & Less often & 22 & 55.52 & & & \\
\hline & Total & 230 & & & & \\
\hline
\end{tabular}

${ }^{\star} p<.01$

According to the Mann Whitney $U$ test used to determine which non-school writing frequency caused significant differences in writing evaluation scores, there were significant differences identified between those who wrote every day and those who wrote once a week in favor of those who wrote every day $(U=2373.500, p=.017)$; between those who wrote every day and those who wrote once a month in favor of those who wrote every day $(U=705.000, p=.000)$; between those who wrote every day and those who wrote less often in favor of those who wrote every day $(U=433.500, p=.000)$; between those who wrote once and week and those who wrote once a month in favor of those who wrote once a week $(U=$ $333.500, p=.000$ ); and between those who wrote once a week and those who wrote less often in favor of those who wrote once a week $(U=217.000, p=.000)$

Findings Related to Correlation of Writing Motivation and Writing Scores

The correlation between the writing motivation and writing scores of the students is shown in Table 4.

Table 4. Correlation Result for Relationship between Writing Motivation and Writing Grade Scores

\begin{tabular}{lrr}
\hline Variables & 1 & 2 \\
\hline WMS (Writing Motivation Scale) & 1 & \\
\hline WEF (Writing Evaluation Form) & $.68^{*}$ & 1 \\
\hline Mean & 65.39 & 38.48 \\
\hline$S D$ & 9.96 & 6.24 \\
\hline
\end{tabular}

${ }^{{ }^{*} p<.01 . N=230 ; S D: \text { Standard Deviations }}$

It can be seen from Table 4 that there is a positive significant correlation between the writing motivation and writing scores of the students $(r=.68, p<.01)$. Accordingly, as the writing motivation of the students' increases, writing evaluation scores also increase. 


\section{Findings Related to Regression Analysis}

The decision was made to apply simple linear regression analysis with the aim of determining the extent that writing success was predicted by writing motivation. Before beginning the regression analysis, it is necessary to ensure that a range of preconditions are met. Firstly, two-way correlations between the variables were investigated and it was made sure that multi-collinearity did not exist. With this aim, the Durbin-Watson value was investigated in the auto-correlation situation and it was concluded that the value obtained (1.72) was within normal limits (Field, 2013). Secondly, the tolerance value of the variance ratio that could not be explained by the independent variable $\left(1-R^{2}\right)$ and the variance inflation factor (VIF) were investigated. As the tolerance value $\left(1-R^{2}=1.00\right)$ was larger than .20 and the variance inflation factor (VIF=1.0) was lower than 10, it was concluded there was no multicollinearity problem (Field, 2013)

After ensuring the necessary preconditions, the simple linear regression analysis results determined that writing motivation explained $46 \%$ of the total variance of writing success $\left(F_{(1,228)}=\right.$ $199.42, p<.001)$. The positive contribution of writing motivation to the regression model was determined to be significant $(\beta=.68, p<.001)$. The prediction of writing success is shown in Table 5 .

Table 5. Predictors of Writing Success

\begin{tabular}{lrrrrr}
\hline & B & $S E$ & $\beta$ & $t$ & $p$ \\
\hline Fixed & 10.49 & 2.00 & & 5.23 & .000 \\
\hline WM & .42 & .03 & .68 & 14.12 & .000 \\
$R^{2}=.46, \Delta R^{2}=.46, p<.001$, WM: Writing & Motivation
\end{tabular}

Discussion and Conclusion

This study aimed to determine the correlation between the writing motivation levels and writing skills of students. In addition, the study investigated the writing motivation levels and writing skills of students in terms of the variables of gender grade level, writing frequency. Based on the findings of this study, the following results were obtained:

Students with high writing motivation scores had high writing evaluation scores. In a study conducted on 4th grade primary school students, Akyol and Aktaş (2018) reported that students with high writing motivation had higher story writing scores. In a study conducted on 617 students from 4th grade to 10th grade level (apart from $8^{\text {th }}$ grade), Troia, Harbaugh, Shankland, Wolbers and Lawrence (2013) concluded that students with high writing motivation had high writing scores A study by Hidi and Boscolo (2006) found that students with higher writing motivation and more willingness to do writing tasks had higher writing performance than students with low motivation and less desire to write. In a study conducted on fourth-grade students in primary school, Takımcıgil Özcan (2014) concluded that students with high writing motivation had higher story writing skills. In her study on $8^{\text {th }}$ grade students, Canitezer (2014) concluded that there was a positive relationship between the writing motivation and the written expression skills of students and that the students with high writing motivation were successful in written expression skills. A study by Bruning and Horn (2000) concluded that motivation was a significant determinant for writing. These results support the results of the present study. In addition, Guay, Ratelle and Chanal (2008) stated that certain factors and motivation positively affect the academic skill levels of individuals.

When the writing motivation scores of the students were examined according to the gender variable, it was determined that female students had higher writing motivation and writing evaluation scores compared to male students. Thus it can be said that female students are more successful in terms of writing motivation and writing studies than male students. The study by Troia, Harbaugh, Shankland, Wolbers and Lawrence (2013) concluded that female students had better story-telling skills than male students. Takımcıgil Özcan (2014) found that female students had higher writing motivation compared to male students. The study by Akyol and Aktaş (2018) concluded that female students had higher motivation than male stu- dents. These results support the results of the present study. Canitezer (2014) concluded that the writing motivation and written expression skills of female student were higher compared to male students.

When the writing motivation scores of students were examined according to the grade level variable, it was determined that the $5^{\text {th }}$ grade students had higher motivation scores than students in the $6^{\text {th }}, 7^{\text {th }}$ and $8^{\text {th }}$ grades. In addition, it was concluded that the $6^{\text {th }}$ grade students had higher writing motivation scores than the $7^{\text {th }}$ and $8^{\text {th }}$ grade students. The grade level with lowest writing motivation scores were determined as the $8^{\text {th }}$ grade. It can be said that as the grade level increases, writing motivation scores decrease. There was no correlation determined between writing evaluation scores and grade level. As was in this study, the study by Troia, Harbaugh, Shankland, Wolbers and Lawrence (2013) concluded that writing motivation was not affected by grade level. They also concluded that writing scores increased with grade level.

When the writing motivation scores of the students were examined in terms of writing frequency, it was concluded that the writing frequency of the students increased with the increase in motivation scores. The writing motivation scores of the students who wrote every day were higher than those who wrote once a week, once a month and less often. Oldfather and Shanahan (2007) stated that writing motivation increases with the increase in the experiences of students in developing their ideas. The writing frequency variable in this study expresses the writing experiences of the students and the fact that the students with high writing frequency also have high writing motivation is an important result of this study. When the writing evaluation scores of the students were examined in terms of writing frequency, it was determined that, as the writing frequency increased, the writing evaluation scores also increased. The students who wrote every day had higher writing evaluation scores compared to those who wrote once a week, once a month or less often. The writing motivation and writing scores of the students with high writing frequency were found to be higher compared to those with low writing frequency.

\section{Study Limitations and Directions for Future Studies}

This study was limited to 230 students $\left(5^{\text {th }}, 6^{\text {th }}, 7^{\text {th }}\right.$ and $8^{\text {th }}$ grades) studying at secondary school, theoretical and practical studies for the concept of motivation, Turkish Language Teaching Program (2018) and the fall semester of the 20182019 school year. This study aimed to determine the relationship between writing motivation and writing skills and concluded that writing motivation affects writing success. Based on the outcomes of this study, the following recommendations have been put forward:

1. Establishing students' writing motivation in writing teaching,

2. Conducting research in writing teaching by taking into account the students' writing motivation,

3. Conducting studies that will facilitate writing motivation in students.

\section{References}

Ackerman, J. (2006). Motivation for writing through blogs (Master of Arts Thesis). Graduate College, Bowling Green State University, Bowling Green, OH, USA.

Akyol, H., \& Aktaş, N. (2018). The Relationship between fourthgrade primary school students' story-writing skills and their motivation to write. Universal Journal of Educational Research, 6(12), 2772-2779. doi: 10.13189/ ujer.2018.061211

Akyol, H. (2013). Türkçe öğretim yöntemleri (6. Baskı), (Book in Turkish). Ankara: Pegem. 
Arıcı, A., \& F. Ungan, S. (2017). Yazılı anlatım el kitabı (4. Baskı), (Book in Turkish). Ankara: Pegem.

Bağcı Ayrancı, B. (2013). Ilköğretim öğrencilerinin yazma becerisinin geliştirilmesinde çağrışım tekniğinin kullanımı [The use of connotation technique for the development of primary school students' writing ability]. Unpublished doctoral dissertation, Gazi University Institute of Educational Sciences, Ankara, Turkey.

Boscolo, P., \& Gelati, C. (2007). Best practices in promoting motivation for writing. In S. Graham, C. A Macarthur and J. Fitzgerald (Eds.), Best Practices in Writing Instruction (pp. 202-222). New York: Guilford.

Bruning, R., \& Horn, C. (2000). Developing motivation to write. Educational Psychologist, 35(1), 25-37. doi: 10.1207/ S15326985EP3501_4

Canıtezer, A. (2014). 8. sınıf öğrencilerinin yazma motivasyonu ile yazılı anlatım beceri düzeyleri üzerine bir araștırma [The writing motivations of eight grade students and their levels of success in writing]. Unpublished doctoral dissertation, Necmettin Erbakan University Institute of Educational Sciences, Konya, Turkey.

Carter, C., Bishop, J., \& Kravits, S. L. (2002). Keys to effective learning. New Jersey: Printice Hall.

Christensen, L. B., Johnson, R. B., \& Turner, L. A. (2015). Research methods design and analysis. Translation Ed.: Ahmet Aypay. (2nd ed.). Ankara: Anı.

Cohen, L., Manion, L., \& Morrison, K. (2007). Research methods in education ( $6^{\text {th }}$ ed.). New York, US: Routledge.

Council of Europe (2001). A common European framework of reference for languages: Learning, teaching, assessment. Strasbourg: Council of Europe.

Creswell, J. W. (2013). Research design: Qualitative, quantitative, and mixed methods approaches. New York: Sage.

Dörnyei, Z. (2001). The Psychology of the language learner. Mahwah, NJ: Lawrence Erlbaum.

Field, A. (2013). Discovering Statistics Using IBM SPSS Statistics (4th ed.). London: Sage.

Graham, S. \& Sandmel, K. (2011). The process writing approach: A meta-analysis. The Journal of Educational Research 104(6), 396-407. DOI: 10.1080/00220671.2010.488703

Guay, F., Ratelle C. F. \& Chanal, J. (2008). Optimal learning in optimal contexts: The role of self-determination theory in education. Canadian Psychology, 49(3), 233-40. doi: $10.1037 / a 0012758$

Güneş, F. (2013). Türkçe öğretimi yaklaşımlar ve modeller (Book in Turkish). Ankara: Pegem.

Harris, K. R., Graham, S., \& Mason L. H. (2006). Improving the writing, knowledge, and motivation of self-regulated strategy development with and without peer support. American Educational Research Journal, 43(2), 295-340. doi: 10.3102/00028312043002295

Hidi, S., \& Boscolo, P. (2006). Motivation and writing (Chapter 10). In C. Macarthur, S. Graham \& J. Fitzgerald (Eds.) Handbook of Writing Research. New York: Guilford.

Karadağ, Ö. \& Maden, S. (2013). Yazma eğitimi: kuram, uygulama, ölçme ve değerlendirme. In Abdurrahman Güze \& Halit Karatay (Eds.), Türkçe öğretimi el kitabı (pp. 265306), (Book in Turkish). Ankara: Pegem Akademi.

Karatay, H. (2013). Süreç temelli yazma modelleri: 4+1 planlı yazma ve değerlendirme modeli. In Murat Özbay (Ed.) Yazma eğitimi (pp. 21-40), (Book in Turkish). Ankara: Pegem.
Kellogg, R. T. (2008). Training writing skills: A cognitive developmental perspective. Journal of Writing Research, 1(1), 1-16. doi: 10.17239/jowr-2008.01.01.1

Kurudayıoğlu, M., \& Karadağ, Ö. (2010). Examining the written expressions of primary school graders as regard to their choice of topics. Mustafa Kemal University Journal of Social Sciences Institute, 7(13), 192-207.

Landers, R. N. (2015). Computing intraclass correlations (ICC) as estimates of interrater reliability in SPSS. The Winnower 2: e143518.81744. doi: 10.15200/ winn.143518.81744

MEB (2018). Yazarlık ve Yazma Becerileri Dersi Öğretim Programı. Ankara: Talim ve Terbiye Kurulu Başkanlığı. Retrieved from http://mufredat.meb.gov.tr/ProgramDetay.aspx?PID $=424$

Nelson, N. (2007). Why Write? A Consideration of Rhetorical Purpose. In Suzanne Hidi \& Pietro Boscolo (Eds.) Writing and motivation (pp. 17-31). Netherlands: Elsevier.

Oldfather, P., \& Shanahan, C. H. (2007). A Cross-Case Study of Writing Motivation as Empowerment. In Suzanne Hidi \& Pietro Boscolo (Eds.), Writing and motivation (pp. 257-278). Netherlands: Elsevier.

Shrout, P. \& Fleiss, J. (1979). Intraclass correlations: Uses in assessing rater reliability. Psychological Bulletin, 86, 420428. DOI: 10.1037/0033-2909.86.2.420

Takımcıgil Özcan, S. (2014). İlkokul 4. sınıf öğrencilerinin yazma motivasyonları ile hikâye yazma becerilerinin değerlendirilmesi [Evaluation of writing motivations and story writing skills in elementary fourth grade students]. Unpublished master's thesis, Sakarya University Institute of Educational Sciences, Sakarya, Turkey.

Tekşan, K. (2013). Yazma eğitimi (Book in Turkish). İstanbul: Kriter.

The Australian Curriculum (2012). English. Australia: ACARA.

The Ontario Curriculum (2006). Language. Canada: The Ministry of Education.

Robson, C. (2017). Bilimsel araştırma yöntemleri gerçek dünya araștırması. (Trans. Ed.: Şakir Çınkır \& Nihan Demirkasımoğlu), (Book in Turkish). Ankara: Anı.

Troia, G. A., Harbaugh, A. G., Shankland, R. K., Wolbers, K. A., \& Lawrence, A. M. (2013). Relationships between writing motivation, writing activity, and writing performence: effects of grade, sex, and ability. Reading and Writing: An Interdisciplinary Journal, 26(1), 17-44. doi: 10.1007/ s11145-012-9379-2

Vaezi, Z. (2008). Language learning motivation among Iranian undergraduate students. World Applied Sciences Journal, 5(1), 54-61.

Wachop, P. (2006). Methods and materials for motivation and learner autonomy. Reflections on English Language Teaching, 5(1), 93-122.

Yaman, H., Sügümlü, Ü., \& Demirtaş, T. (2016). Writing motivation scale: A study on validity and reliability. International Journal of Language Academy, 4(1), 283-294. doi: 10.18033/ijla.370

Yıldız, C., Okur, A., Arı, G., \& Yılmaz, Y. (2013). Türkçe öğretimi (4. Baskı), (Book in Turkish). Ankara: Pegem.

Yıldız, M. (2018). Yazma öğretiminde temel kavramlar. In H. Akyol \& M. Yıldız (Eds.), Kuramdan uygulamaya yazma ögretimi (pp. 2-26) (Book in Turkish). Ankara: Pegem. 
Appendix 1. Writing Evaluation Form

\begin{tabular}{|c|c|c|c|c|}
\hline Field & Substance & 1 (Not Sufficient) & 2 (Must Improve) & 3 (Sufficient) \\
\hline \multirow{9}{*}{ Content } & Subject & $\begin{array}{l}\text { Failed to write a paper on } \\
\text { a topic }\end{array}$ & $\begin{array}{l}\text { Partially wrote a paper on } \\
\text { a topic }\end{array}$ & wrote a paper on a topic \\
\hline & Purpose & $\begin{array}{l}\text { The purpose of the paper } \\
\text { is missing }\end{array}$ & $\begin{array}{l}\text { The purpose of the paper is } \\
\text { partially clear }\end{array}$ & $\begin{array}{l}\text { The purpose of the paper } \\
\text { is clear }\end{array}$ \\
\hline & Main Idea & $\begin{array}{l}\text { Failed to write the paper } \\
\text { around a main idea }\end{array}$ & $\begin{array}{l}\text { Partially wrote the paper } \\
\text { around a main idea }\end{array}$ & $\begin{array}{l}\text { Wrote the paper around a } \\
\text { main idea }\end{array}$ \\
\hline & Secondary Idea & $\begin{array}{l}\text { Failed to write the paper } \\
\text { with secondary ideas }\end{array}$ & $\begin{array}{l}\text { Partially wrote the paper } \\
\text { with secondary ideas }\end{array}$ & $\begin{array}{l}\text { Wrote the paper with } \\
\text { secondary ideas }\end{array}$ \\
\hline & Subject Integrity & $\begin{array}{l}\text { There is no subject integri- } \\
\text { ty in the paper }\end{array}$ & $\begin{array}{l}\text { There is a partial subject } \\
\text { integrity in the paper }\end{array}$ & $\begin{array}{l}\text { There is a subject integrity } \\
\text { in the paper }\end{array}$ \\
\hline & Content Integrity & $\begin{array}{l}\text { There is no content integri- } \\
\text { ty in the paper }\end{array}$ & $\begin{array}{l}\text { There is a partial content } \\
\text { integrity in the paper }\end{array}$ & $\begin{array}{l}\text { There is a content integri- } \\
\text { ty in the paper }\end{array}$ \\
\hline & Consistency & Paper is not consistent & Paper is partially consistent & Paper is consistent \\
\hline & Title & $\begin{array}{l}\text { There is no title in the } \\
\text { paper }\end{array}$ & $\begin{array}{l}\text { Title and the content of the } \\
\text { paper are not compatible }\end{array}$ & $\begin{array}{l}\text { Title and the content of } \\
\text { the paper are compatible }\end{array}$ \\
\hline & $\begin{array}{l}\text { Writing Parts (In- } \\
\text { troduction, Body, } \\
\text { Conclusion) }\end{array}$ & $\begin{array}{l}\text { Paper was not broken } \\
\text { down into parts }\end{array}$ & $\begin{array}{l}\text { There is a partial breakdown } \\
\text { of parts in the paper }\end{array}$ & $\begin{array}{l}\text { The paper was properly } \\
\text { broken down to parts: } \\
\text { Introduction, Body and } \\
\text { Conclusion }\end{array}$ \\
\hline \multirow{4}{*}{ Structure } & Spelling rules & $\begin{array}{l}\text { Did not heed spelling rules } \\
\text { in the paper }\end{array}$ & $\begin{array}{l}\text { Partially used spelling rules } \\
\text { in the paper }\end{array}$ & $\begin{array}{l}\text { There is a proper use of } \\
\text { the spelling rules in the } \\
\text { paper }\end{array}$ \\
\hline & $\begin{array}{l}\text { Punctuation } \\
\text { rules }\end{array}$ & $\begin{array}{l}\text { Did not heed punctuation } \\
\text { rules in the paper }\end{array}$ & $\begin{array}{l}\text { Partially used punctuation } \\
\text { rules in the paper }\end{array}$ & $\begin{array}{l}\text { There is a proper use of } \\
\text { the punctuation rules in } \\
\text { the paper }\end{array}$ \\
\hline & $\begin{array}{l}\text { Readableness } \\
\text { (Handwriting) }\end{array}$ & Paper is not readable & Paper is partially readable & Paper is readable \\
\hline & Paper Layout & Layout is neglected & Layout is partially neglected & Layout is appropriate \\
\hline \multirow{4}{*}{ Wording } & Expression & $\begin{array}{l}\text { The paper is not written in } \\
\text { a clear and understandable } \\
\text { manner }\end{array}$ & $\begin{array}{l}\text { The paper is partially clear } \\
\text { and understandable }\end{array}$ & $\begin{array}{l}\text { The paper is clear and } \\
\text { understandable }\end{array}$ \\
\hline & $\begin{array}{l}\text { Compatibility } \\
\text { with the Target } \\
\text { Audience }\end{array}$ & $\begin{array}{l}\text { The paper is not com- } \\
\text { patible with the target } \\
\text { audience }\end{array}$ & $\begin{array}{l}\text { The paper is partially } \\
\text { compatible with the target } \\
\text { audience }\end{array}$ & $\begin{array}{l}\text { The paper is compatible } \\
\text { with the target audience }\end{array}$ \\
\hline & $\begin{array}{l}\text { Emotion and } \\
\text { Thought }\end{array}$ & $\begin{array}{l}\text { Emotions and thoughts } \\
\text { are not expressed in the } \\
\text { writing }\end{array}$ & $\begin{array}{l}\text { Emotions and thoughts are } \\
\text { partially expressed in the } \\
\text { writing }\end{array}$ & $\begin{array}{l}\text { Emotions and thoughts } \\
\text { are expressed in the } \\
\text { writing }\end{array}$ \\
\hline & Originality & $\begin{array}{l}\text { There is no original expres- } \\
\text { sion in the paper }\end{array}$ & $\begin{array}{l}\text { There is partial original } \\
\text { expression in the paper }\end{array}$ & $\begin{array}{l}\text { There is original expres- } \\
\text { sion in the paper }\end{array}$ \\
\hline
\end{tabular}

